\title{
Mild Non-BH4-Deficient Hyperphenylalaninemia
}

National Cancer Institute

\section{Source}

National Cancer Institute. Mild Non-BH4-Deficient Hyperphenylalaninemia. NCI

Thesaurus. Code C159654.

An autosomal recessive condition caused by mutation(s) in the DNAJC12 gene, encoding dnaj homolog subfamily $\mathrm{C}$ member 12 . It is characterized by increased serum phenylalanine concentrations resulting in variable neurologic defects, including movement defects and intellectual disability. BH4 metabolism is normal. 